BACKGROUND INFORMITION FOR THE ECONOMIC ASSESSMENT OF SOLVENT. FERMENTATION PROCESSES

University of Pennsylvania

January 1977

\title{
INTRODUCTION
}

This work was carried out as part of the economic assessment of solvent fermentation processes. The study was performed by Professor Don $\mathrm{H}$. White while on leave at the University. The basic question raised was whether or not the increased costs for petrochemical raw materials are sufficiently high now (or their projected costs in the 1980's), such that certain chemicals could be produced commercially from a cheaper raw material, say cellulosics, via various fermentation routes. Specific examples under consideration are n-butanol, propionic acid and acetic acid.

This study developed a qualitative approach based on major cost factors of alternative routes for making such projections. The technique herein described can be made as quantitative as desired by applying accepted engineering design and economic analysis principles to the complex, interacting factors that are involved. Some broad qualitative conclusions can be made from this study.

\section{GENERAL APPROACH}

The petrochemical industry has expanded rapidly in the USA in the past due not only to the size of petroleum refineries but also due to the flexibility within these refineries. Consequently, alternative sources were often available for producing cheap raw materials for petrochemicals. This flexibility increased with intensive research over the past few decades upon technologies for manufacturing the broad family of aliphatic olefins.

Thus, in order to evaluate a process route to some product that is in direct competition with a petrochemical, there are multi-factors that must be understood and evaluated. Some of the major factors involved are as follows:

1. World economics

2. Alternative energy (and fuel) sources 


\section{DISCLAIMER}

This report was prepared as an account of work sponsored by an agency of the United States Government. Neither the United States Government nor any agency Thereof, nor any of their employees, makes any warranty, express or implied, or assumes any legal liability or responsibility for the accuracy, completeness, or usefulness of any information, apparatus, product, or process disclosed, or represents that its use would not infringe privately owned rights. Reference herein to any specific commercial product, process, or service by trade name, trademark, manufacturer, or otherwise does not necessarily constitute or imply its endorsement, recommendation, or favoring by the United States Government or any agency thereof. The views and opinions of authors expressed herein do not necessarily state or reflect those of the United States Government or any agency thereof. 


\section{DISCLAIMER}

Portions of this document may be illegible in electronic image products. Images are produced from the best available original document. 
3. Oil (petroleum) ceconomics

4. Olcfins situation

5. Petrocheinical proceseses

6. Petrochemical co-product situations

7. Petrochenical markets

8. Scale of petrochemical operations

The significance of these major factors is outlined and discussed to some extent in the following sections.

\section{WORLD ECONOMICS}

All OPEC countries and developing nations of the World have educated men who attended the best universities of the USA and Europe. They now recognize that their most severe problem is how to raise capital, which in turn can be used for education and industrialization. Paralleling this development (or possibly as a result of it), a feeling of self-determination has become established. Thus, the gross exploitation of underdeveloped countries by Europe, Japan and the USA is coming to a grinding halt.

The economists of the OPEC nations are pricing oil upon the open world marlet at the price they think it can command, taking into consideration to scme extent that price effect upon the worla's gross production capability anà inflation. Other cartels can be expected, possibly for such things as copper, chromium, uranium, phosphates, potash, coffee, tea, sugar and spices.

Recent increases in oil prices, combined with other economic factors, have caused inflation in the USA. However, it has not been nearly as severe as in the rest of the world that depends upon imported oil, including Europe, South America, Japan and the underdeveloped countries. Only the oil exporting countries and a few "in-balance" nations, such as Canada, have faired well during this period.

In the long-range, it appears that the USA will come out with a very healthy economic situation. Fortunately, it is blessed with alternative sources of energy, the capital and the techrology to place itself in an enviable position.

\section{ALTERNATIVE ENERGY SOURCES}

It is beyond the scope of this report to document the tremendous range of alternative sources of energy, when and if the USA decides to utilize them. Therefore, the current trends and future potentials will be given in outline form, only, as follows:

1. Let price of natural gas rise, and use it mainly for heating hoines or for industrial uses that can pay for a clean fuel.

2. Switch electric power plants to coal, havy oils and nuclear power. 
3. Switch autos to diesels if that proves the most cconomic, considering also the disadvantage of the more elaborate air pollution equipment required.

4. Move Liquefied Natural Gas (LNG) and liquid methanol in huge tankers.

5. Generate some gas and liquid oils from coal and cellulosics.

6. Construct shale oil demonstration plants.

7. Obtain some heating by solar energy.

However, the author does want to clarify the situation on how petroleum production per se is being increased at the present time. Off-shore drilling techniques, the pumping of "marginal" oil and recovery techniques are all involved.

Off-shore drilling is partially documented by perusing a few recent issues of the Oil and Gas Journal as follows:

1. North Sea Oil

Crude oil production from the North sea has begun, and is estimated as follows ( 1 ):

\begin{tabular}{lc} 
Year & Million Bbls per Day \\
\cline { 2 - 2 } 1975 & 0.5 \\
1976 & 1.4 \\
1977 & 2.5 \\
1978 & 3.7
\end{tabular}

This is a split of about 2.5 million $b / d$ on the $U . K$. side, with the bulk of the remainder in Norwegian waters.

2. North Sea Gas

The U.K. North sea gas reserves are placed at 26.5 trillion cu. ft. in the southern area, and 18 trillion $\mathrm{cu}$. ft. in the northern oil fields (1). Some southern areas are in full production, averaging 3.5 billion cfd in 1975. It is estimated that by 1980 , production will be 5 billion cfd on the U.K. side and one billion cfd on the Norwegian side.

3. Alaskan Pipeline

The goal is to put the first oil in this nearly \$8-billion pineline July 1,1977 (2). Phase I crude flow is to be $600,000 \mathrm{~b} / \mathrm{d}$, and six months later should reach 1.2 million $\mathrm{b} / \mathrm{d}$. There will be a west coast surplus and an upper Midwest shortage of crude oil at that time. A pipeline is in the planning stage but will not be completed until 1979 or 1980 if approved in the near future (3). 
1. OEE-shorc USA

The Gulf Coast of -shore continues to be the major area of interest, but it is far behind the goals set in 1971 (4). West Coast, East coast, nlaska and the bering sea are active but embroj.led in Government approvals $(5,6,7)$. Thus, some of the pressures of importing oil will be relieved, but continued increased demand keeps the energy picture critical.

An PEA study concluded that tertiary oil recovery techniques in the USA could nearly double present reserves, adding over 30 billion barrels by $2,000(8)$. This study considered only three states, namely, Texas, California and Louisiana (on-shore). The potential recovery is very price-sensitive, as the below diagram indicates. Lower-tier price for old oil $(\$ 5.25)$ would encourage only 3.8 billion bbls by 2,000 , whereas upper-tier prices $(\$ 11.28 / \mathrm{bbl})$ would give the estimated 30 billion barrels. Even higher prices might yield the technically recoverable reserves of some 43 billion barrels.

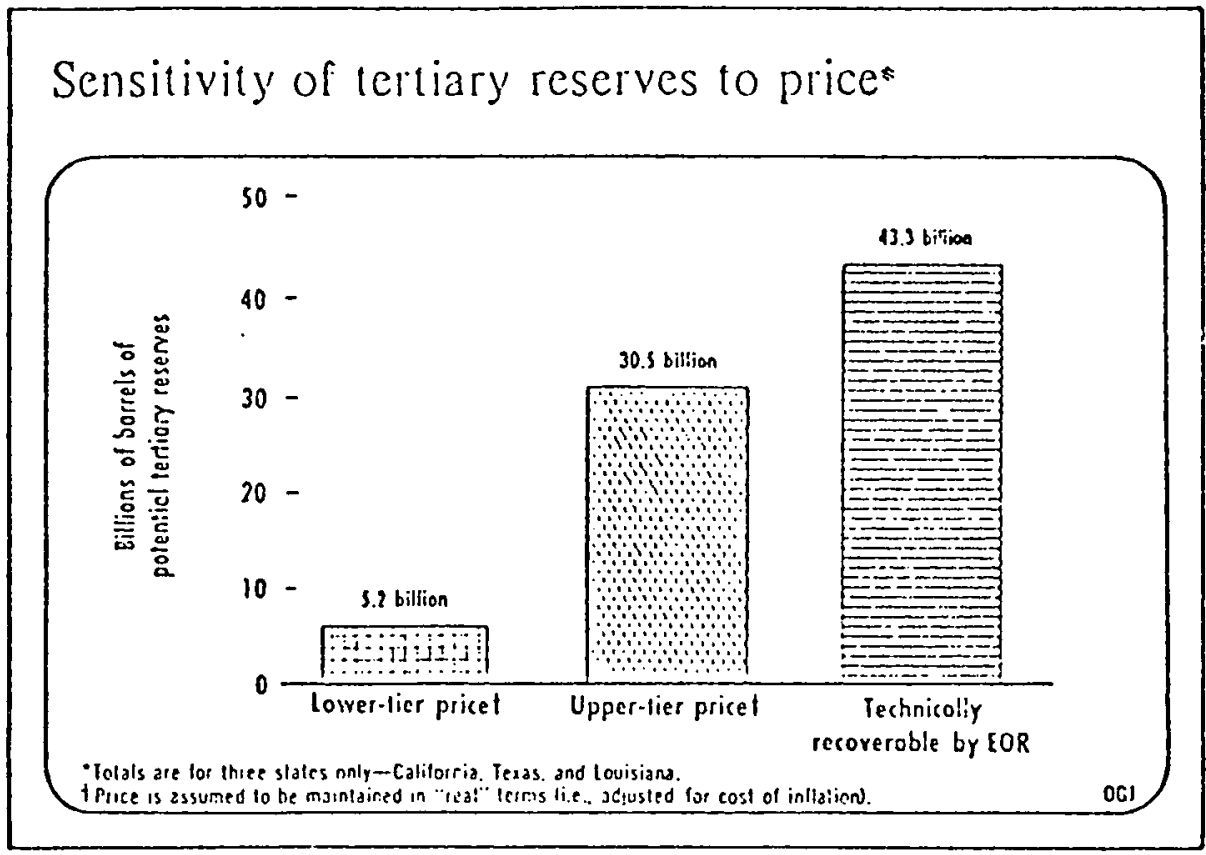

\section{OIL ECONOMICS}

There is concensus that the days of cheap energy (and oil) are gone forevex. It is not clear whether the current high prices for crude oil will decline a few dollars per barrel over the next decade, as increased oil production, increased coal production and other alternate energy sources come into production. These comments and those in subsequent sections are based on the present value of the dollar, and make no attempt to adjust for inflation.

First, however, it should be pointed out that inflation is such that the real increase in foreign oil price is not nearly as great as it appears. The Nelson (inflation) index has risen from 364.9 in 1970 to 681.0 in 1.976 , and is projected, to 708.0 for 1.977 (9). Thus, "old" oil under price control at $\$ 5.25$ 
per barrel is actually selling at a lower price than the typical $\$ 2.70$

per tisrel for domestic ojl in 1970. In a sense, foreign oil at $\$ 11.28$

per jirrel sold at about $66.00 / \mathrm{bb}$. in 1976 . Domestic oij. and natural

gas are under jrice control, and are being decontrolled very slowly in

order to minimize their effect upon the usn economy.

The economists of the OPEC nations (trained at prominent USA and European business schools) have very astutely priced middle-east oil at "just about the right price". First, it is at a price that the world markets can afford and probably absorb economically. A few nations, like Italy, are having great difficulties, but the USA, Japan and west Germany appear to be surviving. Great Britain is in real financial trouble, but expects to be self-sufficient in oil by 1978-1980. The OPEC nations have probioly taken this into consideration. For example, they are heavily involved in buying real estate in London at the present time. Second, the OPEC oil prices are encouraging tertiary oil recovery (see last section) and off-shore drilling but it appears that such oil must be sold at just about OREC prices in order to obtain a reasonable return on investment.

Conoco (in oil, gas and coal) predicts the energy demand in the USA will increase $2.5 \%$ year to 1990 (just 13 years away), compared to the 4.1 annual growth rate in the $1960-73$ period (10). Conoco also predicted that oil imports would increase from $6.9 \mathrm{million} \mathrm{b} / \mathrm{a}$ in 1976 to $13 \mathrm{million} \mathrm{b} / \mathrm{d}$ in 1990, a 90 percent increase. This will be due to present slow movement to alternate energy sources, such that. if present trends continue, in 1990 the USA energy needs will be provided as follows:

\begin{tabular}{lcc} 
Source & $\$$ in 1976 & $\frac{8}{2}$ in 1990 \\
\cline { 2 - 3 } Oil and gas & 74 & 62 \\
Coal & 3 & 22 \\
Nuclear & 19 & 12 \\
Other & $\frac{4}{100}$ & $\frac{4}{100}$
\end{tabular}

Many people argue that decontrol of product prices should be instituted, and let competition and demand set the prices. Most are in agreement that in the long run this should be done. As of July 1, 1976, price and allocation controls on middle distillates and diesel fuel lapsed and congress refused to bloci Federal Energy Administration (FEA) proposals for decontrol (11). FEA Administrator Frank G. Zarb planned to also decontrol gasoline prices in the Fall of 1976, but the outcome of this is not herein verified.

A further current complication is that EPA is attempting to complete the conversion to no-lead gasoline, but it could result in a $1977 \mathrm{U} . \mathrm{S}$. gasoline shortage (12). Gasoline consumption slowed down in 1974 and 1975, but is running at an all-time peak in 1976, well over 7 million $b / d$. If the lead limit is lowered too fast, there may be a gasoline shortage during each forthcoming summer for the next few years. There are many older reforming units which at maximun cfficiency can yield only 93 octane, and must depend upon lead for the ethyl grades.

It is beyond the scope of this report to discuss the complex interactions within a given petrolcum refincry, including (a) the flexibility of making more gasoline in the sumncr and more fuel oil in the winter and (b) the alternate use value for pricing various fuels and petrochemical feedstocks. Some understanding of these interactions will be achicved as the olefins and petrochemicals are analyzed. However, it should be pointed out that propjlene 
produced in cat cracking operations has traditionally been recovered to produce high octane blending components, i.e., alkylate and cat poly gasclirice. propylene-based alkylate will remain an important contributor to rool octane, bccause it is three octane units higher than unleaded gasoline and 8-12 higher than the 1976 leaded grades (13).

\section{OLEFINS}

A 42-gal barrel of oil wejghs about 300 pounds, such that at "old oil prices" it was worth about one cent per pound. Crude oil today from the OFEC nations is nearly four cents per pound. Considerable insight on both oil refinery operations and how certain petrochemical feedstocks are generated can be obtained by studying a 1974 report by Lummus (14). The upper part of Figure 1 shows that a reasonable amount of ethylene and propylene can be produced at an estimated crude oil processing cost of $\$ 26.06 / T$ (just a little over a cent per pound of crude) by utilizing ordinary atmospheric distillation and pyrolysis of naphtha. However, by going to vacuum distillation (lower part of Figure 1), the ethylene and propylene yields can be more than coubled, but at an operating cost of about $\$ 41.75 / \mathrm{T}$ (about two cents per pound). These simplified diagrams of a portion of a typical refinery illustrate refinery flexibility (but at some added investment and operating costs).

Obviously, olefin technology and economics are inter-related (especially ethylene and propylene), but some of the highlights and distinctive features of each will be given in the sections below.

\section{Ethylene}

The production and price of ethylene in the USA is given in Figure 2 (15). Ehtylene came down in price until 1974, when it increased sharply to 6 cents per pound. Today, at the end of 1976 it is about $11-3 / 4$ to $12-1 / 4$ cents per pound (16). The demand had risen to over 20 billion pounds per year in 1974, and is projected to $35-40$ billion pounds by 1980 (17). Nine projects totaling 8.8 billion annual pounds wert announcer as of 1974 for completion through 1978. Through 1980, another 6.5 billion pounds will probably be added to this planned expansion. It should be noted that all plants do not normally run at capacity (see Figure 3).

Historically, the USA has made ethylene from ethane and propane, recovered from natural gas. Since Europe did not have natural gas, it has relied heavily upon cracking naphtha or gas oil to ethylene. It is projected that most future ethylene in the USA will come from heavier feedstocks. One significant factor involved is the decreascd yields involved, which typically are as follows (18)

\begin{tabular}{lc} 
Feedstock & Lb etrylene/lb Feed \\
\cline { 2 - 2 } Ethane & 0.78 \\
Propane & 0.41 \\
Butane & 0.36 \\
Naphtha & 0.32 \\
Gas oil & 0.23
\end{tabular}

Due to low:cr yields from naphtha or gas oil, the capital investment per pound of cthylene'is much higher than for a plant operating on an 


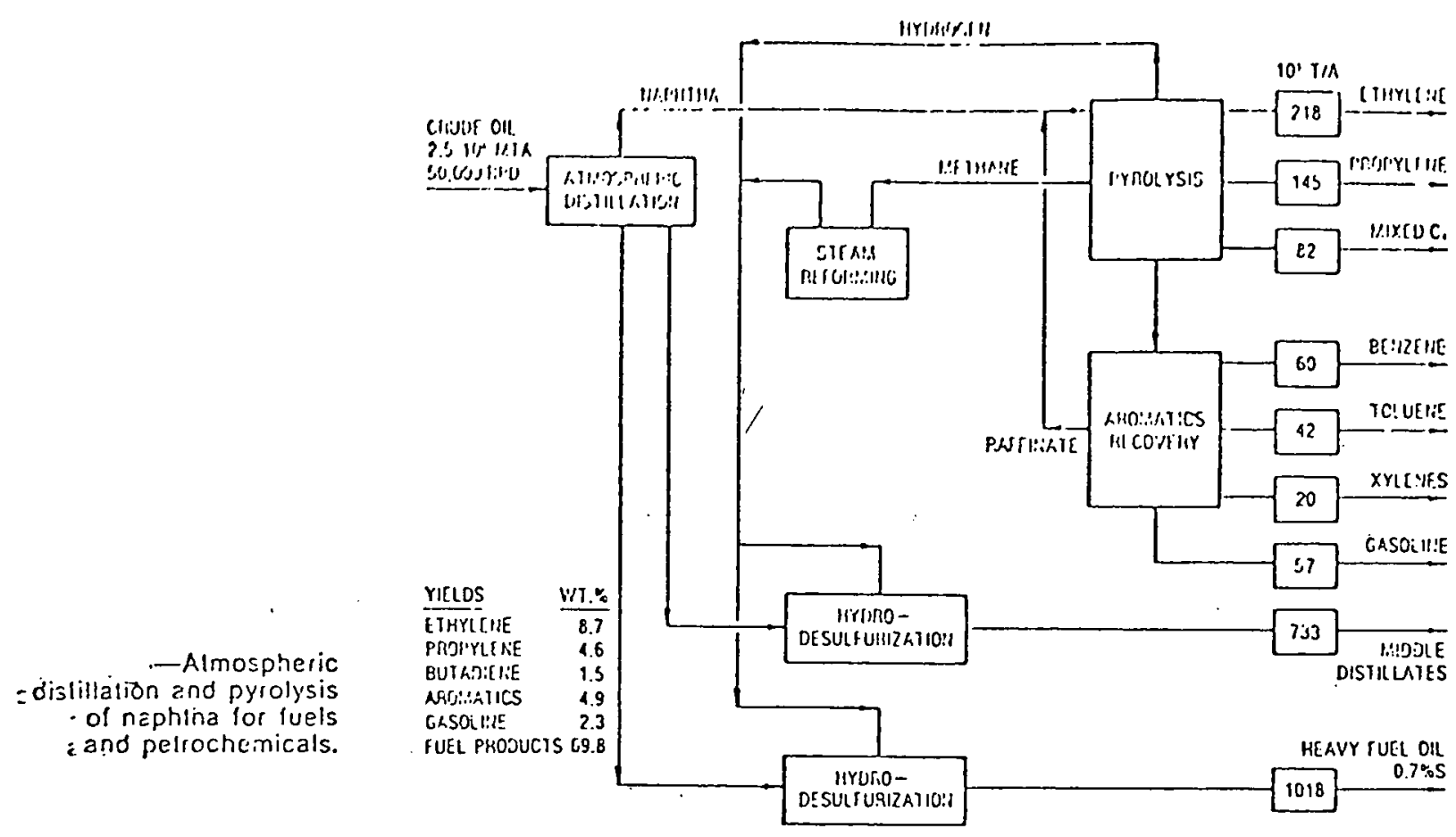

TOTAL IIVESTISENT $150 \times 10 \mathrm{~S}$ CPUDE OIL PROCESSING COST $26.05 \$ \mathrm{~S} / \mathrm{T}=3.56 \mathrm{~S} / \mathrm{BBL}$

\section{MORE PETROCHEMICALS FROM CRUDE}

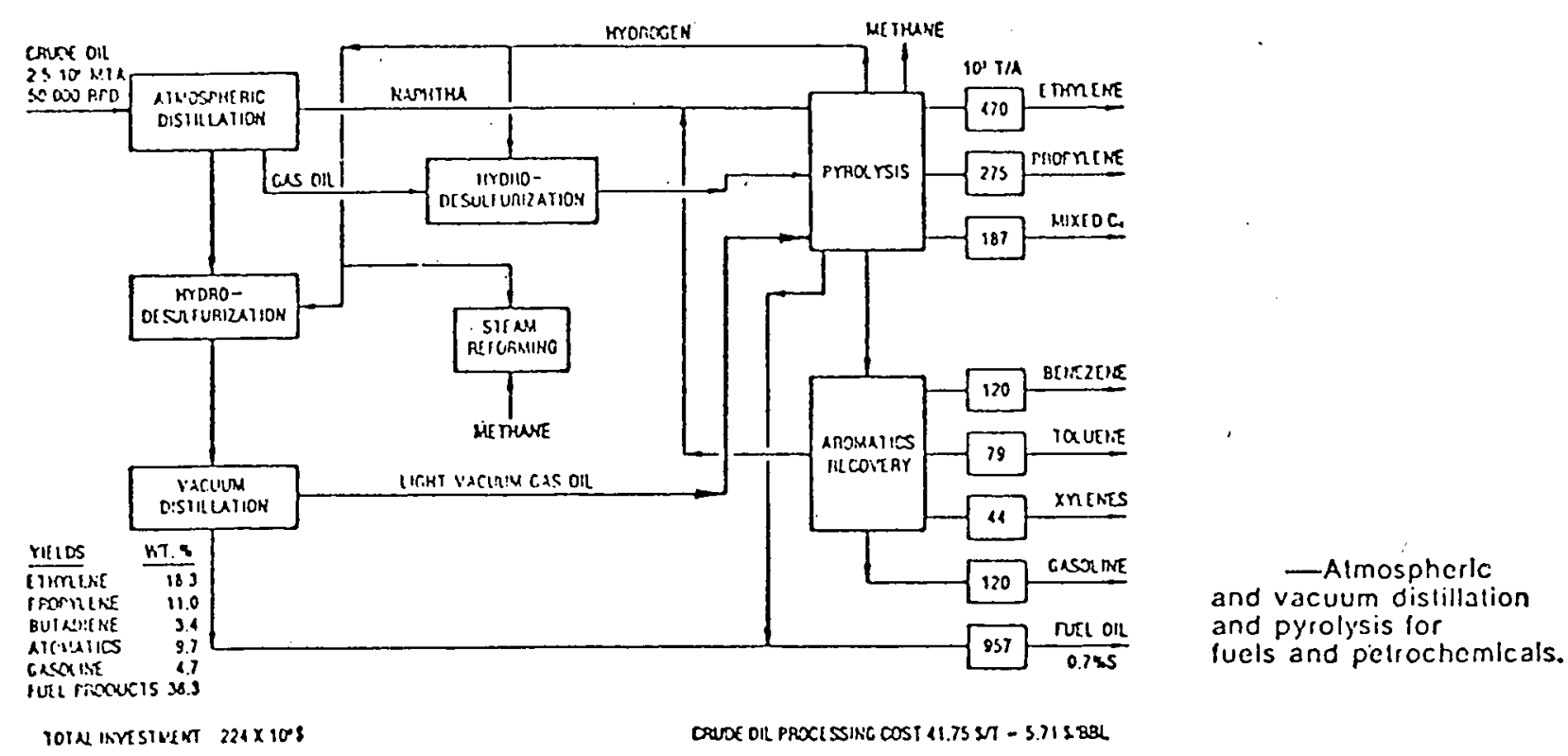

Fig. 1. Flexibility of refinexies for ethylene and propylene 

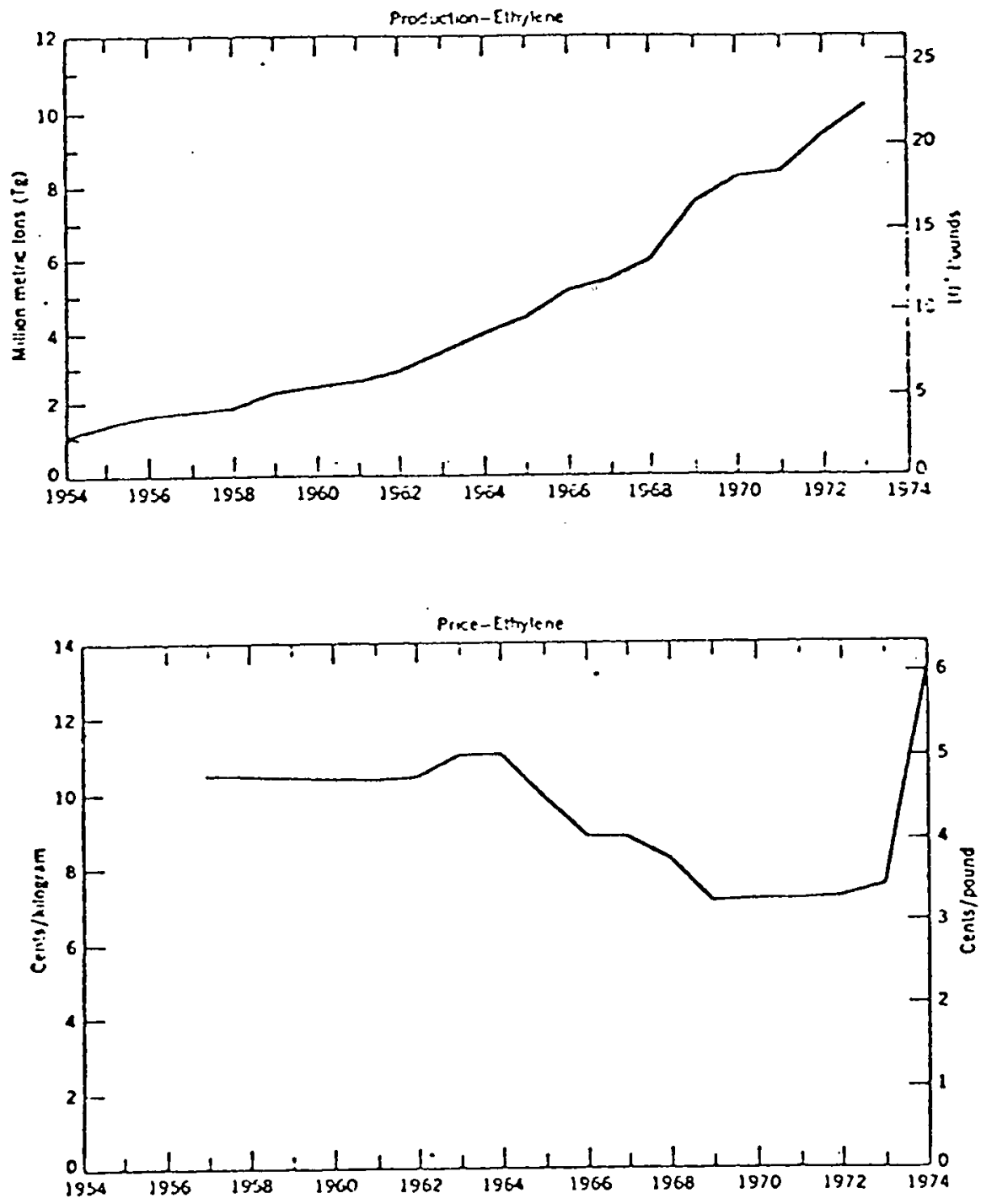

Fig. 2 Ethylene production and price to 1974 
U.S. ethylene balance through 1980

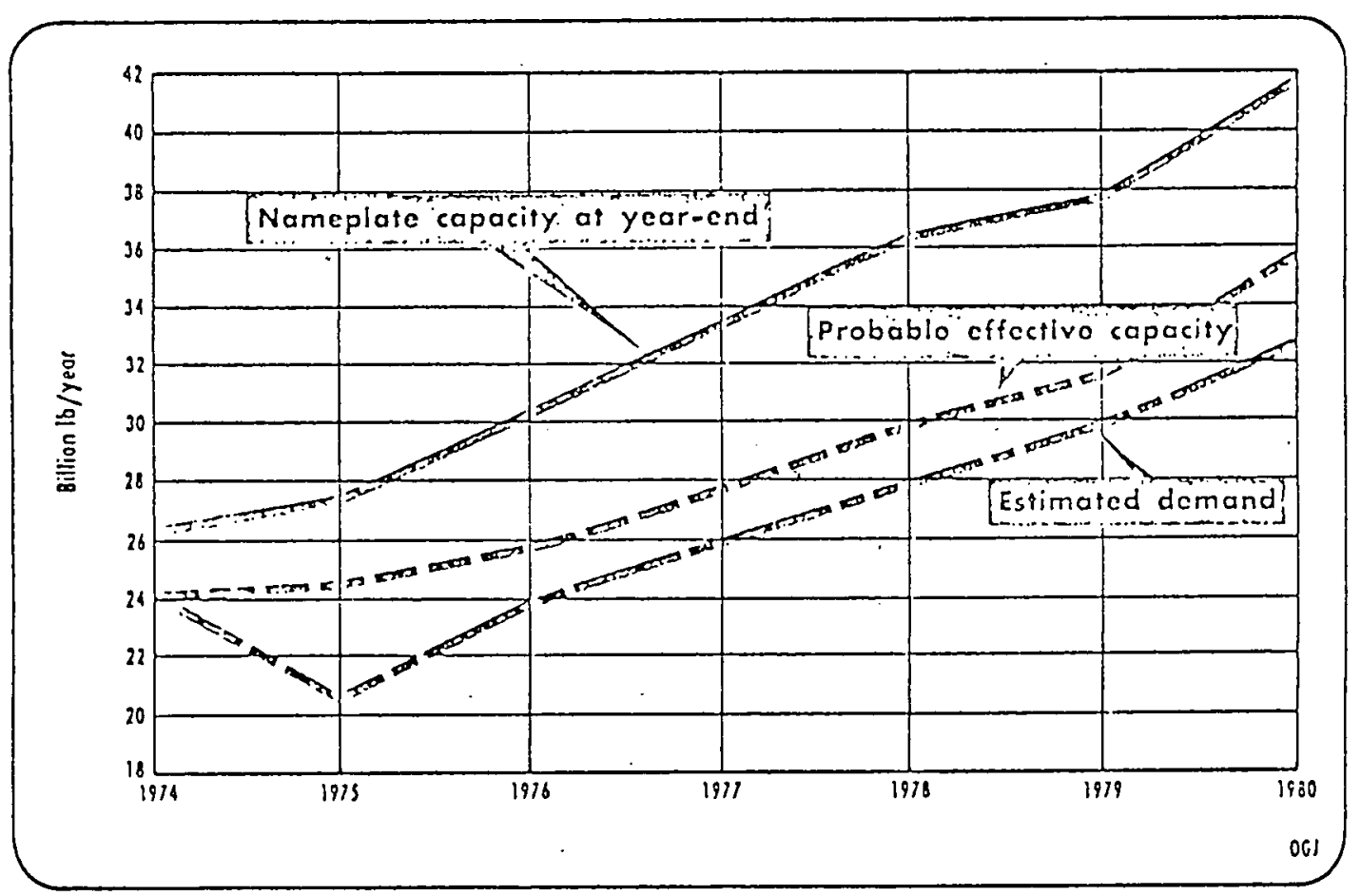

Fig. 3. Ethylene balance in USA through 1980 
ethane fecel:;tock. However, the economics are very tricky, because increased yicler; of valuable by-products are obtained from naphtha or gas oil, and thus nake the cconomics for ethylene bettex than one might expect. Based on a projectcd value of 5.6 cents per pound naphtha feedstock in 1980, one cost estimate yields ethylene at 19.1 cent per pound for a 15 percent return on investment before taxes (17). For a more realistic 25 percent return on investment before taxes, ethylene price in 1980 would be 22.3 cents per pound.

The pricing of feedstock and by-products are critical in these projections. Naphtha has been priced over the years at about one cent per pound over crude oil price, or at about two cents per pound as shown in Figure 4 (14). In 1974-75 naphtha came into short supply on a world-wide basis, and increased in price to some 12 cents per pound. Many literature discussions project a price of 5 to 6 cents per pound in 1980, as being a more realistic price when supply and demand are in balance again. Since straight-run naphtha can be obtained from crude oil by simple distillation, a manufacturing charge of about a cent per pound (as in the "old days") is possibly a good figure. This, of course, assumes that all of the other fractions (products) from the same crude oil can be sold at a fair profit. Thus, if crude oil is \$12 to \$15 per barrel in 1980, then naphtha should be priced at 4 to 4-3/4 cents plus a cent manufacturing charge, or about 5 to 6 cents per pound.

Union Carbide has always been (and still is) one of the leaders in ethylene technology. The author is impressed by the approach currently being taken by union Carbide, namely, cracking an aliphatic crude oil at very high temperatures at short residence times (19). This is a joint development with the Japanese, who earlier had devised a process to yield considerable acetylene from crude oil cracking using a $20 \mathrm{msec}$ residence time. The union Carbide approach is to use slightly longer residence times at $2,000^{\circ} \mathrm{C}$ to give considerably higher yields of ethylene (34-36 percent) and also several important by-products. These include 2-4 percent acetylene, 6-12 percent propylene and 3-6 percent butadiene. Union Carbide adnits to a one to two cent per pound cost advantage over conventional naphtha/gas oil cracking. Taking the same projections on prices and capital costs as assumed by Struth (17), as discussed in an earlier section above, these cost advantages could prove to be even greater, as shown by the following rough calculation:

Costs, Cents per Pound Ethylene

\begin{tabular}{lcc} 
& Costs, Cents per Pound Ethylene \\
\cline { 2 - 3 } & $\begin{array}{c}\text { Naphtha } \\
\text { Cracking }\end{array}$ & $\begin{array}{c}\text { Union Carbide } \\
\text { Crude Cracking }\end{array}$ \\
Feedstock Cost & 18.8 & 11.8 \\
By-Product Credit & $\frac{13.0}{5.8}$ & $\frac{14.0}{(2.2)}$ \\
Net Feedstock & 5.0 & 5.0 \\
Operating Costs & 3.5 & 3.5 \\
Capital Costs & $\frac{5.0}{13.3}$ & $\frac{5.0}{11.3}$ \\
Profit (158 return before taxes) &
\end{tabular}




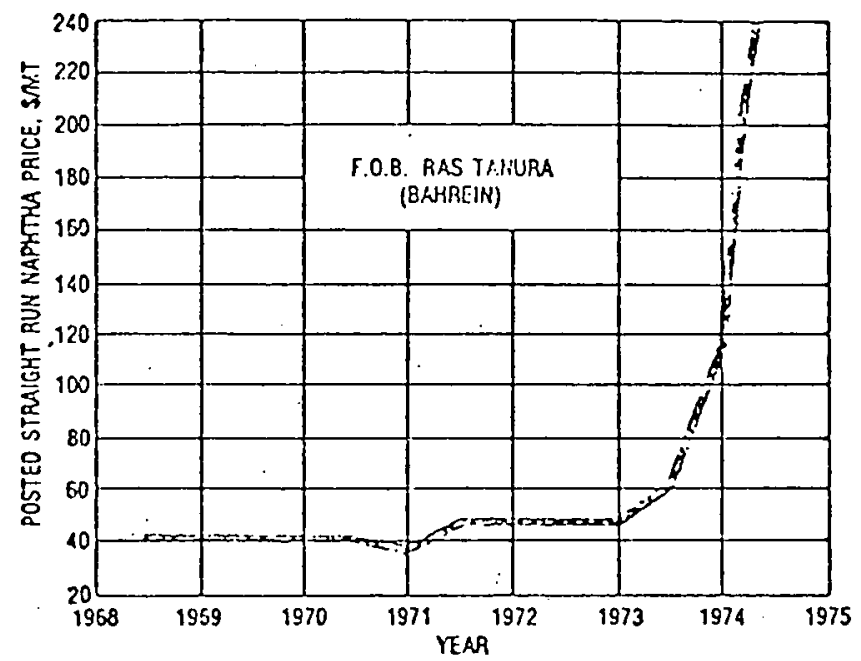

- History of straight run naphtha posted prices, $\$ / M T$, f.o.b. Ras Tanura (Bahrein), Pciroleum Times.

Fig. 4 Naphtha price to 1974 
Trus, it can be seen how great an arlvantage Union carbide inight have by (a) successfully utilizing the much chcaper ficedstock (aljphatic crude oil) and (b) cracking at very short residence times at such high temperatures (about $2,000^{\circ} \mathrm{C}$ ) to give increased yiclds of the more valuable products, namely, ethylene, propylene and butadiene. The above calculation on the Union Carbide process assumes $\$ 15 / \mathrm{bbl}$ crude oil price, and a capital investment equal to that for cracking and purifying the co-products from naphtha. These would appear to be valid assumptions.

In summary, as the USA moves to heavier feedstocks for ethylene, one can argue that the price of ethylene will go to 19 to 23 cents per pound. For any competitive operation, however, one should be cautioned that improved technology (as already demonstrated by Union Carbide) and the fierce competition among the ethylene producers (some 23 at this date -- see Table 1) would keep the price in the range of 12 to 15 cents per pound.

\section{Propylene}

Up until mid-1974, propylene price was tied closely to its value as an alkylation feedstock by producing high octane blending components for gasoline. Thus, propylene was valued at 2.5 cents per pound in a refinery stream when alkylate sold for 14 cents per pound for use in high octane gasoline (20). Currently, chemical-grade propylene is priced at $8-3 / 4$ cents per pound and polymer-grade propylene at $9-1 / 2$ cents per pound (16).

As shown in the two parts of Table 2, in 1974 about 16.2 billion pounds were produced in normal refinery operations and an additional 7.5 billion pounds were made by steam crackers. It should be noted that, in a sense, in the latter case the propylene was the by-product of the ethylene production, which had to be made by steam crackers. A total of 13.2 billion pounds were used in alkylation and for other fuels, with 11.2 billion pounds going into chemicals and polymers $(21,22)$.

Insight on how proplene has been priced for use in motor fuels, and on how a refinery operates, is given by Baggett (20) as follows:

From thesc 1970 alkylation cconomics it would appear that propylene would now be ligh valued as a alkylate feckstock since wholesale: gasoline priecs are now near

From Fig. 1, a look at the 1970 propylene alkylation cconomics shows that the value of contained properlene in a refinery grade strcam was $2.5 \% / \mathrm{lb}$. when alkylate sold for $1 . \mathrm{F} / \mathrm{g}$ al. and the jolsutane price was $6 \mathrm{~g} / \mathrm{gal}$. Adeling an uperoding charge of $0.5-0.75 \% / 1 \mathrm{l}$, and the propylene s.2les price would be 3-3.25\%/lb. These economics are cxtremely sensitive 10 isobutane and alliplate priccs. In 1970, illemane: fecolsteck usages for prop) lene were in proprane he heling or nalumal g.as substitution. This

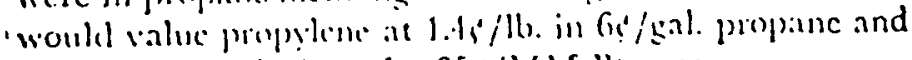

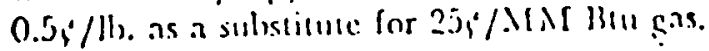
32 \%/gal. and alkylitc valued at 1-2̧/gal. higher. Howcrer, the oppositc is truc. While gasoline has doubled in wholesale price, isobutanc is now $4-5$ times higher than 1970 prices.

The 1974 propylane alkylation economics (Fig. 1) show's current values which can be ralized by making propylene alkylate. Lising current market prices of $30 \mathrm{s.}$ gal. for isobutane and $32 \% / g a l$. for alkylate, the contained propylene is only worth is/lb. This sccms impossible when teliay contract propylone is sclling from $6-85 / 16$. and spot is $10-12 q / 1 b$. 
Table 1

Ethylene producers in the USA

U.S. ethylene nameplate capacity at year-end

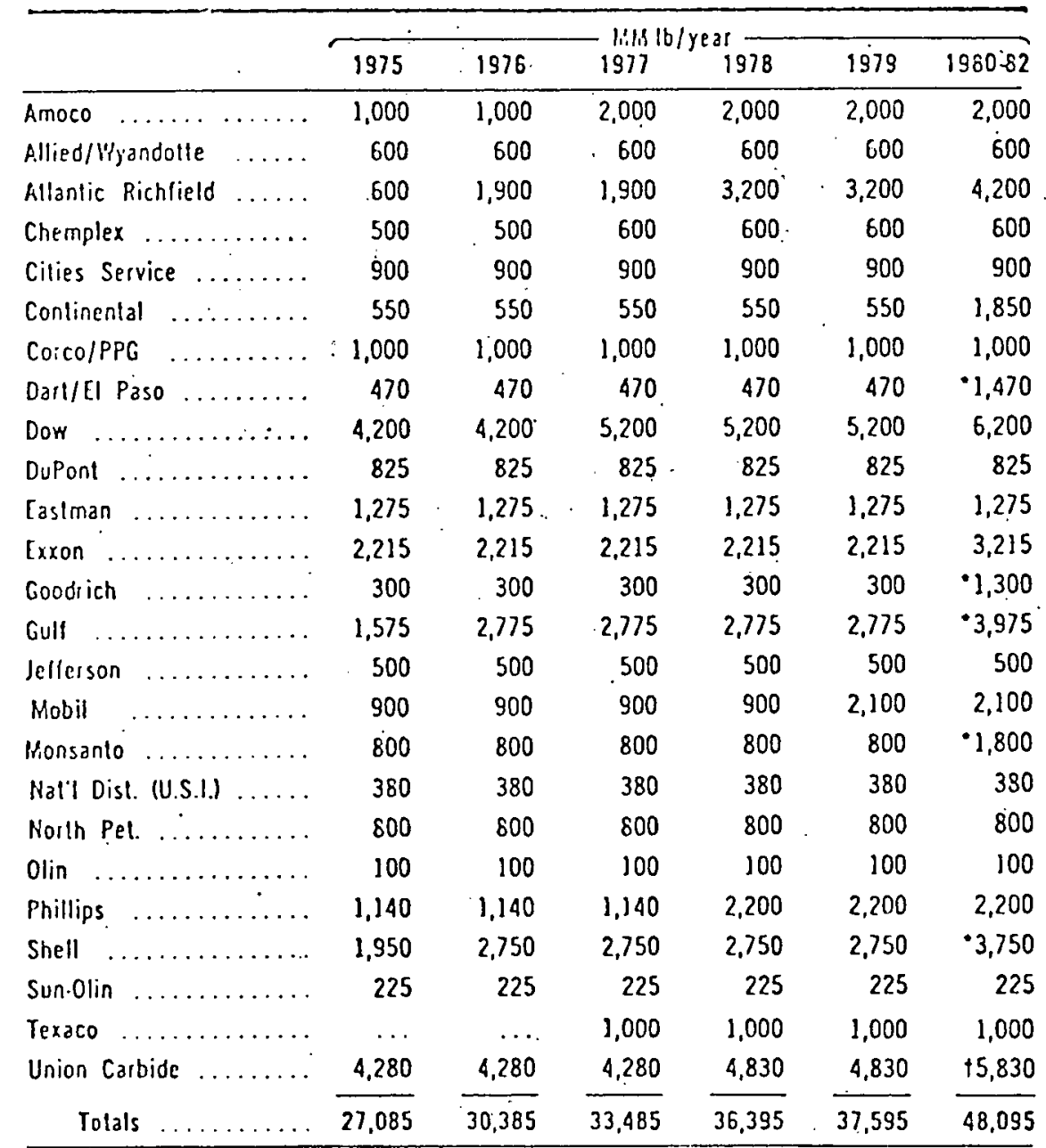

- Speculative 1 Join venlure with Siandard Oi! Co. (Ohio) 
Table 2

Propylene sources in 1974
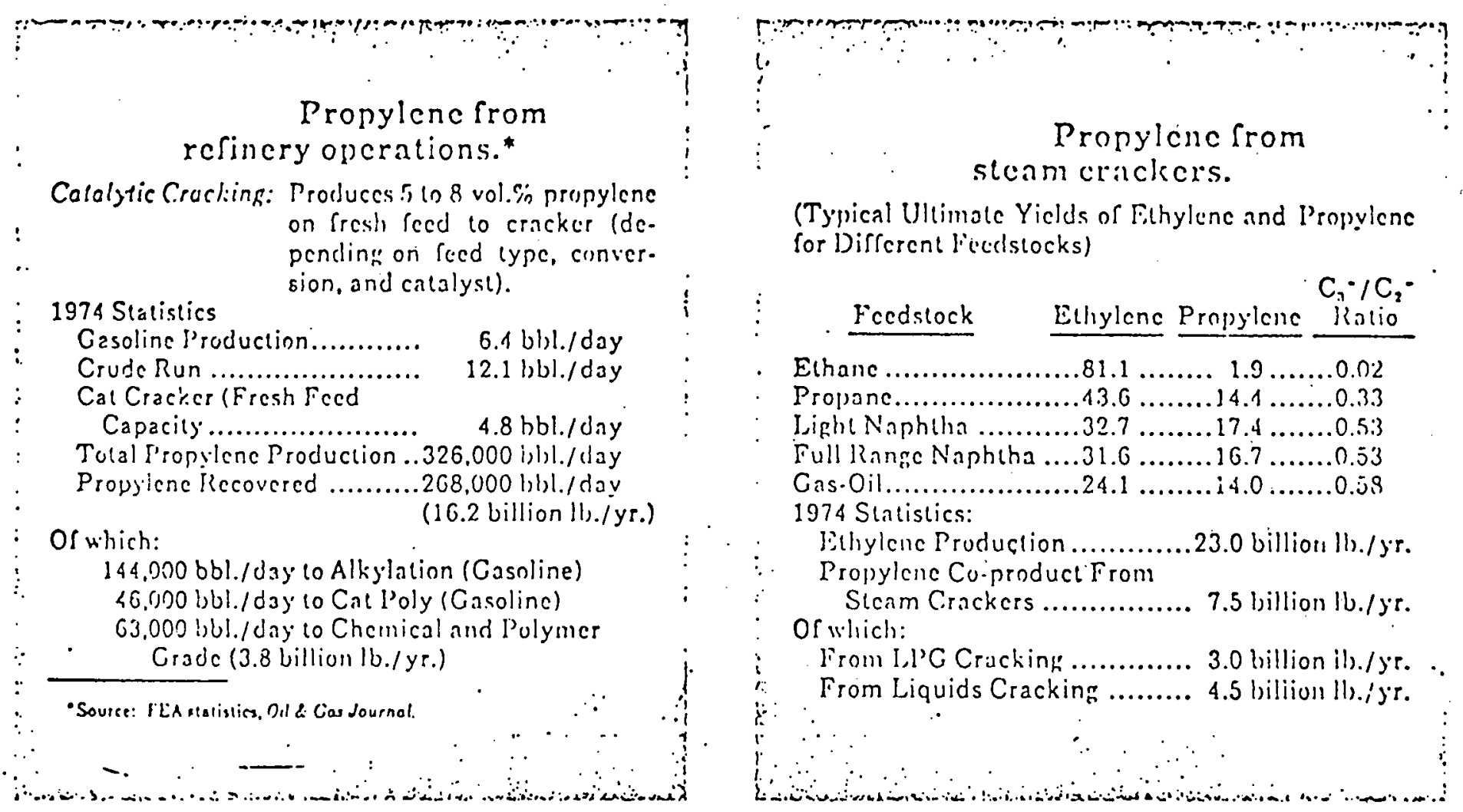

(Typical Ultimole Yiclds of Flhylene and l'ropulene for Different Fecedslocks)

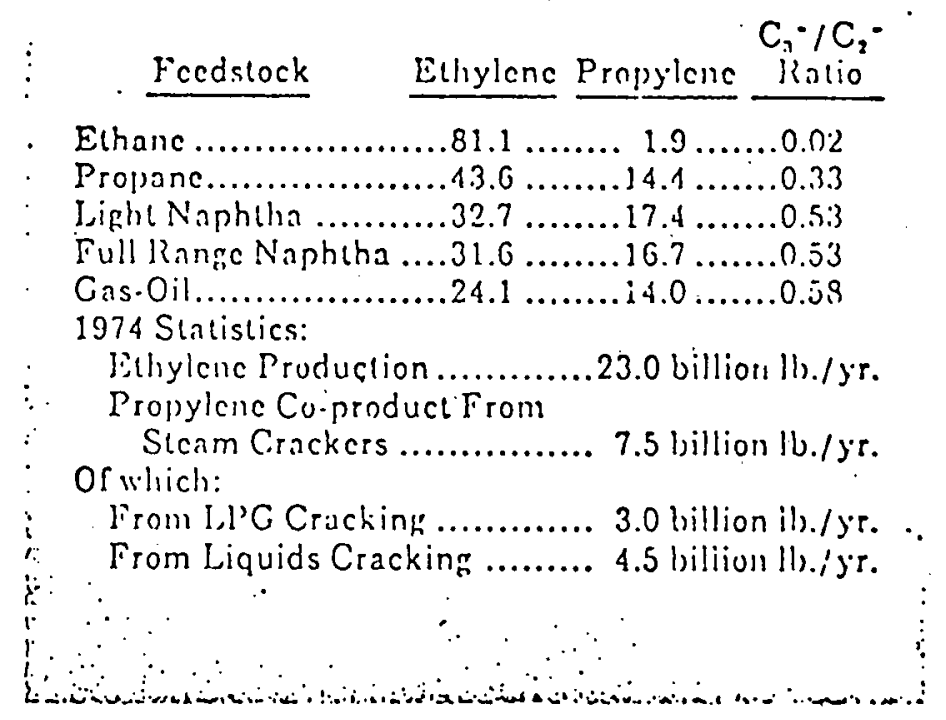


Why would refiners continuc to alliyline propylene for gasoline? Hirst, refincrs are buying isobutanc at 18-20 6 Gal. at price controlled contracts-this malics containcd propylene worth 4.9-5.26/lb. Second, the refiner also malies some isobutane and his transfer price is somewhat less, improving economics further. Finally; the refiners busincss is making gasoline-by whatever action neccssary to maintain volume and quality.

Currently, alternate propylene values are $5.75 \% / 1 \mathrm{~b}$. in

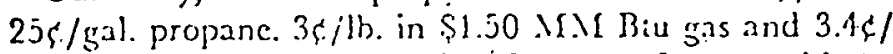
1b. in $\$ 11$ barrel fuel oil. Therefore, a refircr would not alkylate incremental propylene if he must purchase spot isobutane. In today's excess toluene martet it is more desirable to sell propylene and replace alkylate with aromatics.
Existing propylene alkylation units will continuc operat. ing using $C_{4}$ 's first, and then using $C_{3}$ 's to balinnec their octanc: pool. Spot jobutane purchizses will be linited until no-lead grasoline becomes the major martet-reguiring all the octane available. Sccond, gasoline prices will be held down and not allowed to reach European levels. Third, the LPG marlict or the replacement of other fuels will provide refinery grade propilene the best alermate value for incremental propylene. In the next 2 or 3 years, this base value will be $4-6 \mathrm{f} / \mathrm{lb}$. of contained refincry grade propylenc. Uising current 1-1.jc/lb. upgrading fecs, spot propylene should sell for no less than $5-7.5 \mathrm{c} / \mathrm{lb}$. in 1974 1976. This is the base price during shortage periods and through mid-1976; chemical grade contracts will sell for 2-3G/lb. higlicr. Spot propyliene (particularly imports) can command ncar $20 \mathrm{c} / \mathrm{lb}$.

It is believed that in the future the price of propylene will tend to be priced on its value as a by-product (co-product?) of ethylene in steam crackers. Thus, for several reasons, it will probably lag the price of ethylene by 3 to 5 cents per pound. Furthermore, this will occur gradually over the next. few years because it will take sorne time before all autos are running on no-lead gasoline; thus, propylene will continue to be tied to some extent to its value in alkylation.

For the steam cracking of gas oil to ethylene and propylene in 1975, Spitz (22) estimates the economics as shown in the left side of Table 3. Thus, if ethylene is priced at 11.4 cents per pound, then the coproduct propylene is worth 6 cents per pound. He projects gas-oil steam cracker economics to 1979 (see right side of rable 3) whereby if ethylene is priced at 17.5 cents per pound, then the co-product propylene is worth 11.5 cents per pound. However, from all of the economics discussed in the literature, the author believes propylene will be priced in the 9-10 cent per pound range, with the co-product ethylene from gas-oil steam cracking being more like 19-21 cents per found. One, must keep in mind, however, as discussed previously, the Union Carbide process could drive down both ethylene and proplylene prices (and profits from operating gas-oil steam cracking plants) in 1980.

\section{Butadiene and Isoprene}

A detailed discussion of these two prime diolefins, used to prepare the "new types" of isotactic synthetic rubber is not of direct interest in this study. It is suffice to state that the world war II and post-war approach of dehydrogenation of a purified butene-l and its subsequent purification (butadicne) is now in trouble in the USA economically. Wherever ethylene is produced from the heavier feedstocks (naphtha and gas oil, rather than butane), the direct production of butadicne as a co-product has been more economical than by the dehydrogenation of butene-1 (23). Thus, arcas outside of the 
Table 3

Propylene/ethylene Gas-oil Cracker Economics in 1975 and 1979

\section{Startup economics of a} gas-oil cracker, 1975.

\section{Economics}

million $\$ / y r$.

Raw Matcrials \& Utilities (Gas.Oil at $\$ 10.50 / \mathrm{bhl}$.)

Opcratin! Costs, Overhead, and

S.C.A. Costs ................... 11

Capital Charres (Depreciation

plus 2j\%: Return Before Tax)..

Tolal.

\section{0}

11

Tolal ...............

(Incl. Ci, Ci, l'yro. Gasoline and $\mathrm{Fucl} O \mathrm{Oil)}$

$\overline{\$ 236}$

Applicable to Elhylene and

Propylenc Price ..................\$ 152

Required Olefin Silles Pitce ........ $9.3 \mathrm{e} / \mathrm{lb}$. (av..)

If Propylene Realization Is (c/lb.): $\mid$\begin{tabular}{l|r|l}
0 & 7.5 & 9
\end{tabular} \begin{tabular}{l|l|r|r} 
Ethylenc Price Must Be (6/lb.): & 11.1 & 10.5 & 0.6
\end{tabular}

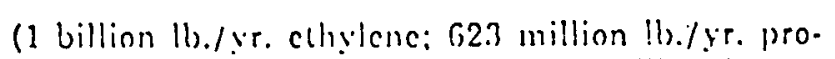
pylenc. "Jotal fixed linvestment: $\$ 230$ million.)

\section{Shirlup (economics of a} fils-oil eracker, 1!)7!).

(1 hillion Hb./yr., chyjlenc; 02.3 million |b./sr., propuylenc)

\begin{tabular}{|c|c|}
\hline 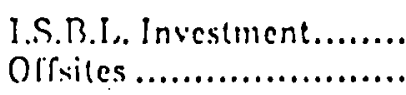 & $\begin{array}{l}\text {.. } 200(0) \text { million } \\
\text {.. 1:0) million }\end{array}$ \\
\hline Polnl Fixed Investment & ...5390 million \\
\hline F.connmics & million $s / y s$. \\
\hline
\end{tabular}

(Gias-Oil ats15/bht) ......\$214

Opcrating Conts, Utcrhand, and s.(i.A. Costs .......................... 15

Capitill Charpes (Deprecintion plus

25:. Return Beforc Tax)................ 125

Byproduce Credit:

(Incl. $C_{i}, C_{i}$, Pyro. Gasoline.

and Fuel Dil) .......................110

Applicable to lithylene and

l'rnpylene Price............................\$2.17

Required Olclin Sales Price.............. $15.1 \mathrm{e} / \mathrm{lb}$.

If Propylenc Realization Is (c/lb.): $|10| 11.5 \mid 13$

Ethylene Pricc Must Bc (c/1b.): $\mid 18.5$ | $17.5 \mid 10.6$ 
Urited Stilces, e.g., Jipan, Vicst Germany, United Kingdom, Italy ard France, are operating on co-product butadiene.

In the USA, co-product butadiene amounted to 32 percent of total production. It will increase steadily through the early 1980 's as heavier feedstocks are utilized for ethylene, as discussed earlier.

The same situation prevails for isoprene, an alternate feedstock for the isotactic rubbers.

\section{PETROCHEMICAL ALTERNATIVE ROUTES}

There are a multitude of alternative routes to most petrochemical products. Therefore, it is important to detect any new trends, which lead to the abandonment of the then established commercial routes in favor of the new ones. Usually, as the volume of a new process route increases, the economics of large singletrain plants lead to a rapid shut-down of the old route. For example, ethylene chemistry displaced acetyiene chemistry in the late 1950's as the first truly large ethylene plants were built. Currently, the dehydro plants for butadiene are being shut down. In a later section, the demise of n-butanol via fermentation is discussed.

As discussed in an earlier section, a trend toward cracking heavier feedstocks to ethylene and propylene has been initiated, and there is nothing on the horizon (except possibly similar co-product operations from coal two or more decades from now) that can stop this trend. Another trend (discussed in detail under n-butanol) is the production of higher aldehydes via the new low-pressure catalytic oxO process.

\section{SCALE OF SINGLE-TRAIN OPERATIONS}

Historically, petrochemicals have had three major economic factors that led to their rapid growth. These were cheap raw materials, flexibility of co-product manufacturing with reasonably simple purification by distillation and the huge size of single-train operations. They may be losing their economic edge in raw material costs due to the OPEC crude oil pricing. Co-production advantages still exist as discussed in previous sections. Large-scale economics still exist, as outlined in this section by a few major (key) examples.

\section{Catalytic Fluidized-Bed Reactors}

Typically, 80,000 to 100,000 barrels per day of a heavier feedstock can be put through a single unit, standing some 7-10 "floors" in height, operatea by about 4-6 men per shift. Thus, some 10 billion pounds:per year are processed in a "single-train" unit with all of its inherent economic advantages. Even at only 10 percent conversion per pass, this is a "billion pound per year" product unit.

2. Three-Phase Methanol Fluidized-Bed Reactor

As an example in the thinking of how to process synthesis gas to methanol in huge units, chem systems Ine. is developing with EFRI financial support a three-phase fluidized-bed reactor which can be reasonably large (24). It utilizes an incrt circulating hydrocarbon to fluidize a solid catalyst and to remove the heat from the highly exothermic syn gas $\left(\mathrm{CO}+\|_{2}\right)$ reaction to methanol. It is visualjzed that at a catalyst volume space velocity nf 
$4,000^{-1}$ with a 45 percent per pass conversion at 1,125 psi with a temperature outlet of $250^{\circ} \mathrm{C}$, a production rate of $1,80^{\circ}$ tons per day of methanol could be achieved in a single reactor. This is; equivalent to about 1.2 billion pounds per year.

3. Iarger polycthylene Production Train Units

The size of single-train polyethylene production lines has incrcased steadily over the past two decades, going from 5,000-10,000 tons/yr to 20,000-50,000 tons/yr to 100,000 tons/yr to the present designs of 180,000 tons/yr trains (25). This is a production rate of 360 million pounds per year using one compressor, one reactor and one extruder. Thus, the step-wise decrease in costs for LDPE plants have been estimated as follows : Capacity of Single train, $\mathrm{mm}$ Lbs per Yr.

$\begin{array}{lccc} & 120 & \underline{120} & \underline{360} \\ \text { Investment } & 1 & 0.62 & 0.50 \\ \text { Personnel } & 1 & 0.56 & 0.38 \\ \text { Maintenance } & 1 & 0.63 & 0.51 \\ \text { Spare part stocks } & 1 & 0.72 & 0.58\end{array}$

It is interesting to note that a tubular reactor of about $50 \mathrm{~mm}$ diameter can produce the 240 million pounds of polyethylene per year at some 38,000-42,000 psi reaction pressure. It was stated that a plant with an output of 360 million pounds per year requires larger tube diameters "which have recently been made possible by new manufacturing techniques" (25).

\section{Oxo Pressure Peactors}

For $C_{4}$ oxo products, single-line systems are now up to about 160,000, tons per year. This is equivalent to about 320 million pounds per year. It should be noted that such reactors in conventional oxO processes must operate at some 3,000 to 6,000 psi pressure.

\section{CONSIDERATION OF SPECJFIC CHEMICALS}

Three specific chemicals that appear attractive from a fermentation technology standpoint are n-butanol, propionic acid and acetic acid. They have (a) reasonably high conversion efficiences and (b) potentially cheaper raw materials based on renewable cellulosics. The economics of these factors in each case should be compared with the corresponding petrochemical route, expecially with respect to complexity of technology and the size of single train units. Such detailed economic studies are beyond the scope of this study. However, the key competitive petrochemical routes that should be considered are outlined in the following sections.

\section{1. n-Butanol}

The alcohol n-butanol. has had a reasonably steady growth to about 500 milijion pounds per year at a price of about lil cents per pound by $1973(20)$. since then its price has increased sharply to 22 cențs per pound at the preisent time (16). Its growth and price up to 1974 are shown in Figure 5 (26). 

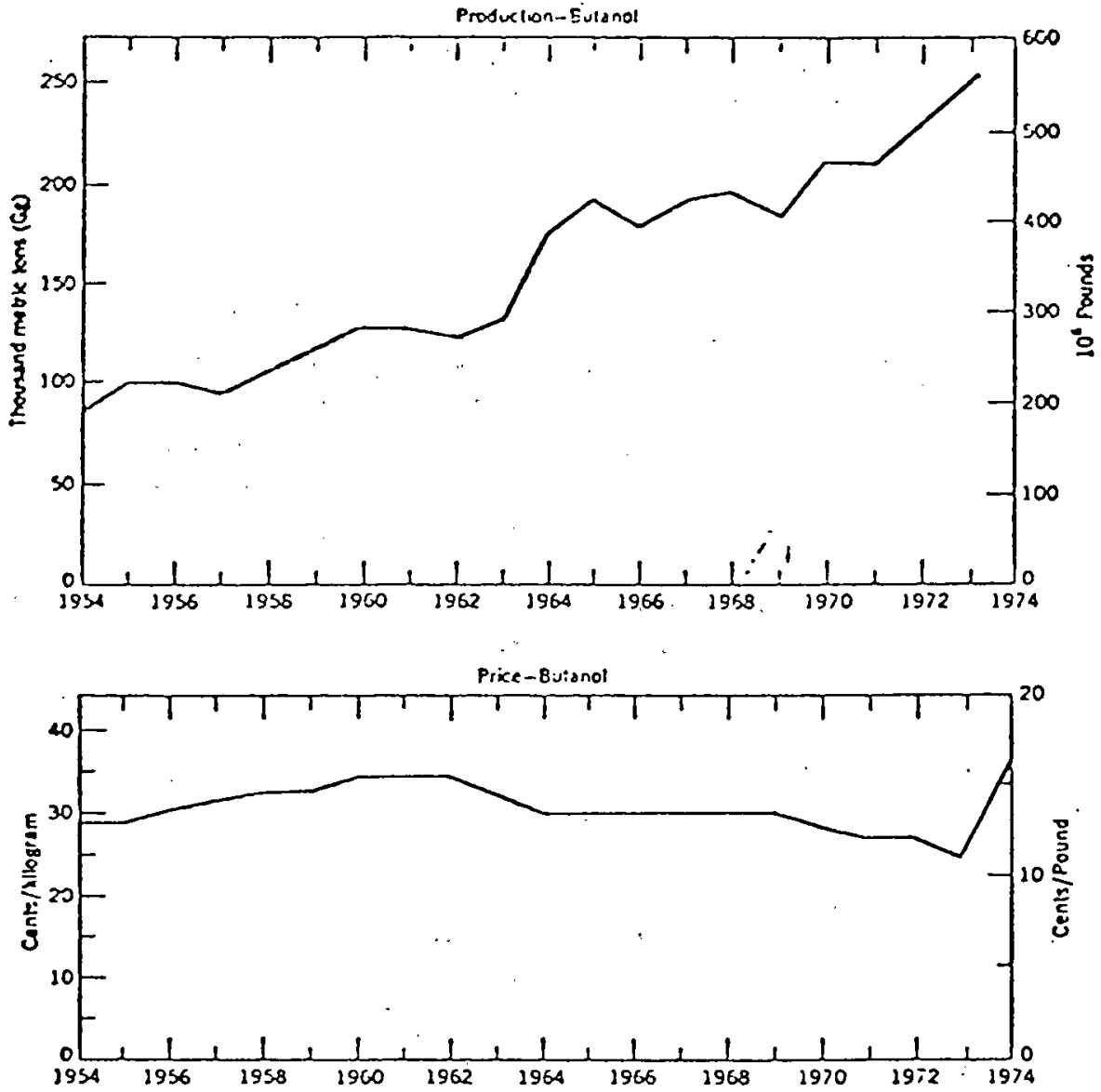

Fig 5. Production and price of n-Butanol to 1974 
Ithere are 12 conyanics probucing n-futanol, 11 of which are listed below as; gives in Ref. 26:

\author{
Manufacturers and Plant Sites \\ Celanesce Corp., Pishop. Texas; Ciear lake, Texas (n-) \\ Commerical Solvents Corp., Terre Haute, Ind. (n-) \\ Continental Oil Co., Westlake, La. (n-) \\ Dow Badische Co., Frecport, 'Texas ( $n$-, iso-) \\ Exxon Chemical Co., Baton Rouge, La. (n-, sec-) \\ W. R. Grace and Co., Fords, N. J. (n-, iso-) \\ Oxochem Enterprise, Penuelas, P. R. ( $n-$, iso-) \\ Publicker Industrics, Inc., Philadelphia, Pa. (n-) \\ Shell Chemical Co., Deer Park, Texas (n-, sec-, tert-) \\ Texas Eastroan Co., Longview, Texas $(n-)$ \\ Union Carbide Corp., Seadrift, Texas; Penuelas, P. R. (n-)
}

These same 11 companies plus Ethyl Corporation are listed in a Gulf Universities Research Consortium report (27). There are two predominant synthesis routes which have driven all fermentation plants out of business except two (apparently Commercial solvents and Publicker Industries). These synthesis routes are as follows (26):

a. Condensation of acetaldehyde to form aldol, which is dehydrated to crotonaldehyde, and then hydrogenated to n-butanol.

b. Synthesis of n-butyraldehyde from propylene and synthesis gas $\left(\mathrm{H}_{2}+\mathrm{CO}\right)$ by the oxo process, separated from the co-products, and hydrogenated to $n$-butanol.

It is reported that fermentation now accounts for cnly 6 percent of production, with about 60-70 percent by the oxo process and about 20 percent by the acetaldehyde route. With the old prices for ethylene. (the raw naterial for acetaldehyde) and propylene (for the oxo process) it would appear that either synthetic process would be more economical than fermentation wherever the plant size can be made large:

There has been a technological breakthrough in the oxo process technology' over the past 10 years. Again, as in ethylene technology, it is Union Carbide that has come up with an exciting new oxo process $(28,29)$. A rhodium cataly'st process can be operated at about $300 \mathrm{psi}$ and $100^{\circ} \mathrm{C}$, instcad of the $3,000-6,000 \mathrm{psi}$ and $145-180^{\circ} \mathrm{C}$ required for the conventional oxo process with cobalt catalyst. The lower temperature results in less condensation side-reactions, but more importantly the catalyst selectivity for $n$-butyraldehyde is much higher. A normal/iso butyralaehyde product ratio of 10-16 can be achieved, compared with a $3-4 \mathrm{n} / \mathrm{iso}$ ratio in the conventional oxo process. This is very important because n-butyraldehyde has two large marlicts, namely, (a) hydrogenation to n-butanol and (b) (b) aldol concensation and hydrogenation to 2-ethylhexanol. On the other hand, isobutyraldchyde is utilized mainiy to produce isobutyl alcohol, which comes in a distant second to $n$-butanol in the market place. 
The corventional. OxO process has been utilized to produce the higher alcohols for use in preparing esters for use as plasticizcrs in the plastics industry. Today, there are 35. companies throughout the World who are using the oyo process, some of whom own several such facilities (30). This same reference lists the more important plasticizer alcohols and the production capacities for some of the corresponding plasticizers as follows:

Important plasticixer alcohols

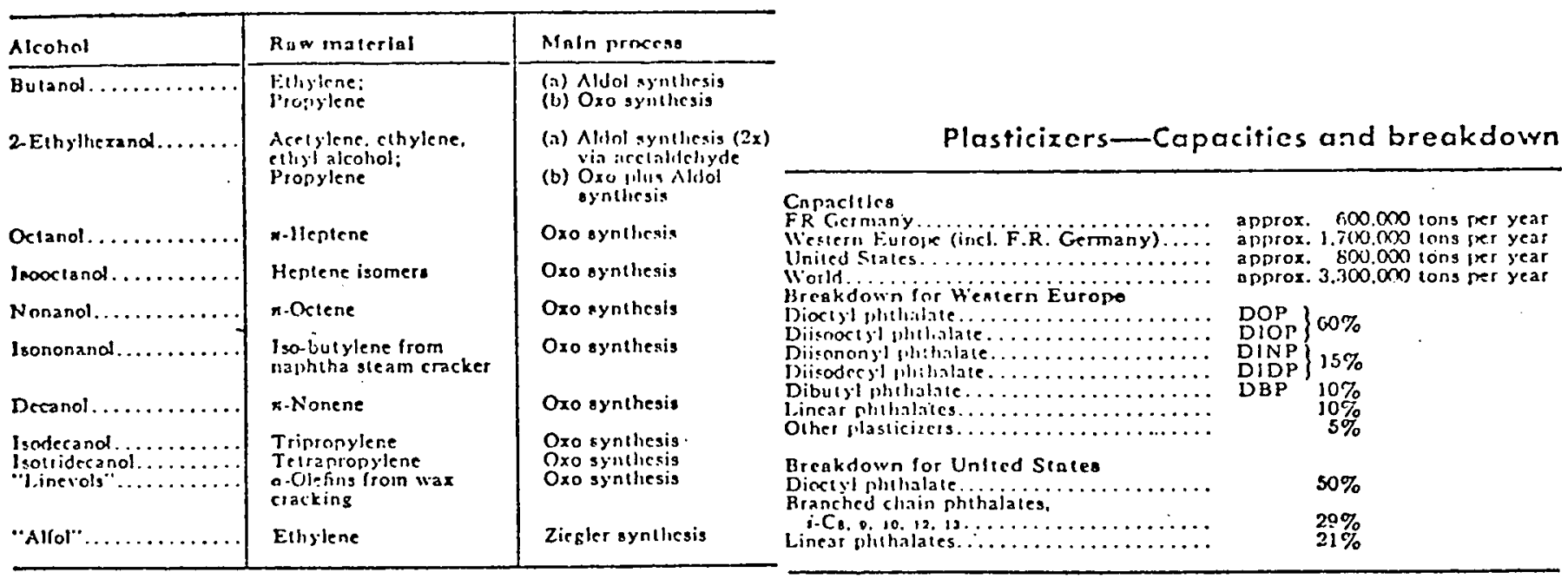

Thus, it can be seen that the oxo process has been directed mainly toward the production of $\mathrm{C}_{8}$ to $\mathrm{C}_{20}$ alcohols for making phthalate ester plasticizers. However, such plants can produce in blocked out operation n-butyraldehyde from propylene to make $n$-butanol as well as the specific alcohol 2-ethylhexanol. The economics of such an operation using the new Union Carbide process must be studied in looking at n-butanol fermentation routes.

The use pattern of n-butanol in the USA, as of 1974, is as follows (26):

Solvent

n-butyl acetate

Butyl acrylate and methacrylate

Glycol ethers and esters

Plasticizers

Amine resins

Misc. and export
Percent

25
10
15
15
10
15
10
100

The acetone by fcrmentation process first gave $n$-butanol as a byproduct. However, n-butanol became the main product for use in the expanding lacquer industry, including painting autos. However, cars have gone to alkyd plastic paints and many other lacquer uscs have been displaced. The demise of the lacguer industry has been predicted for a long time, but it continues to hold on, with some uses decreasing and new applications increasing. 
$-22-$

The most cycjting potential application of $n$-isutanol being followed by the author (other than in plastjedicars and polymers) is the potential neced for alcohols for the microenulejon flooding processes for tertiary oil recovery (27). The culf Universitics Research Consortium, funded by EHDR and private industry, had originally set a yoal of devcloping and putting into operation such techniques so that by 1986 we would be recovering $500,000 \mathrm{~b} / \mathrm{d}$ of tertialy oil. A morc realistic goal of $200,000 \mathrm{~b} / \mathrm{d}$ is now being considered. Nevertheless, large quantities of chenicals will be required in these operations, depending upon the performance and costs of the potential chemical systems. Based on the projected need for three pounds of alcohols per barrel of oil, even the modest start of $200,000 \mathrm{~b} / \mathrm{d}$ recovery would require about $416 \mathrm{mili}$ ion $1 \mathrm{~b} /$ year of alcohols. Based on costs of $13-15 \mathrm{f} / \mathrm{lb}$ for isopropyl alcohol, $20 \% / \mathrm{lb}$ for $\mathrm{C}_{4}$ alcohols and 30-40\%/lb for higher alcohols, it was reported that probably a 50/50 mixture of isopropyl/higher alcohols would be used. From the standpoint of the alcohol incustry, howcver, there is always the danger of the alcohols being abandoned in favor of increasing the sulfonate/oil ratio. Current thinking is that, if economics permit, 10 pounds of sulfonate, 3 pounds of alcohols and one pound of polymers would be used per barrel of oil recovered.

In sumiary, the author concludes that the potential of $n$-butanol in tertiary oil recovery, in plasticizers and in polymers (such as cellulose butyrates) should be examined. He also cautions that the new union Carbide oxo process appears to be formidable competition to producing $n$-butanol via fermentation.

\section{Propionic Acid}

It appears that there is sparse information on propionic acid, although a thorough search of recent literature was not conducted. Apparently, it is not yet a large commodity chemical. Its current price (synthetic grade) is quoted as $20 \frac{1}{2}$ cents per pound (16). The question is whether no large markets have developed because it has been too expensive in the past or whether it does not have a technical use that can be satisfied better by another material.

It is known that union Carbide has applied its new oxo technology to bring on stream in early 1975 at Texas City a unit designed to produce 100 milition pounds per year of propionaldehyde from ethylene (29). It has demonstrated a production capability of about 50 percent over design capacity. Propionaldehyde is currently priced at 25 cents per pound (16). No doubt union Carbide is converting some of this production to propionic acid.

One old technical reference (in 1951) was found that indicated that the conversion of propionaldehyde to propionic acid by oxidation was about 90 percent (31). With all of the modern reseaxch that has been done upon the direct oxidation of various organics, it is certain that an efficient system is being used.

The author recommends that celancse be contacted to see if cellulose propionate has any desirable properties that can't be covered by the fanily of collulose butylate plastics. Currently, the chemical Marketer lists the latter at the following price levels (16): 
Plaritic

Cellulose acetate/butyrate

$\begin{array}{ll}" & " 1 \\ " & "\end{array}$

\begin{tabular}{|c|c|c|}
\hline $22 z$ & $"$ & \\
\hline $8 \%$ & $"$ & \\
\hline 0 & " & \\
\hline & " & \\
\hline
\end{tabular}

Price, Conts/Pound

79

103

82

94

84

The author seems to recall that some 20 years ago, Bell labs preferred cellulose propionate as the molding material for phone sets, as having the "xight feel and warmth" for the hand and ear.

In summary, it appears to the author that, again, a fermentation process for producing propionic acid could not compete with the Union Carbide oxo process. The latter is tied directly to the price of ethylene, and the feedstock for propionic acid via fermentation would have to have some cost advantages. This nay be possible, and should not be overlooked.

3. Acetic Acjd

Acetic acid has had a steadily growing market, tied directly to the growth of the plastics field. The growth and price up to 1974 are shown in Figure 6, showing 2.4 billion pounds pex year in 1974 at a price of about 9 cents per pound (32). Its current price has increased sharply to 17 cents per pound (16).

Its use pattern in 1974 was as follows (32):

Use

Vinyl acetate

Cellulose acetate

Acetic esters

TPA/DMT

Textile processing

Miscellaneous

\section{Percent}

$$
\begin{array}{r}
40 \\
23 \\
12 \\
10 \\
3 \\
12 \\
\hline 100
\end{array}
$$

The situation for acetaldehyde and acetic anhydride should be injected at this point, because they are closely tied to acetic acid in the synthetic field. Acetaldehyde is a billion pound a year chemical at an "old" price of 9 cents per pound, as shown in Figure 7 (33). Its price has risen sharply to 18 cents per pound (16). Acetaldehyde is mentioned at this time because about 50 percent of it is consumed to make acetic acid and acetic anhydride, the latter mostly in a process that yields equi-molar products of acetic acid and acetic anhydride. Also, acetic anhydride is a 1.6 billion pound a year chemical at an "old" price of 12 cents per pound in 1974, as shown on Figure 8 (34). Its current price has risen sharply to 23 cents per pound (16). Acetic anhydride is mentione here, because (a) most of it is made from acetic acid and (b) attention should be called to the fact that about 95 percent of its use is for cellulosic esters, including cellulose acetate, cellulose acetatc/butyrate and cellulose acetatc/propionate.

Back to acetic acid, its process technology is tied closcly to ethylene and methanol, the two principal fecdstocks. A very good review article on the many alternate process routes for acctic acid production was pre- 

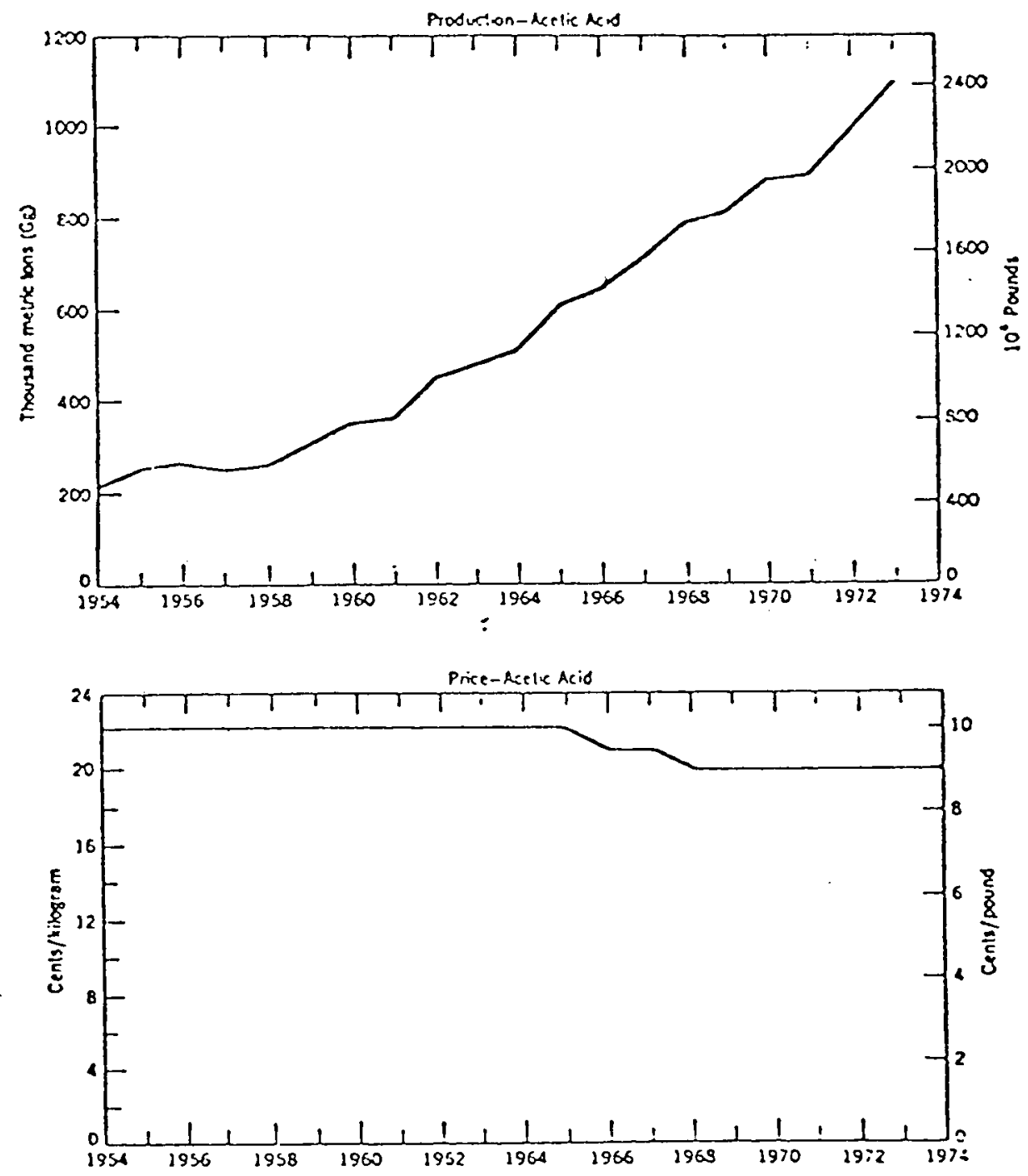

Fig. 6. Production and price of acetic acid to 1974 

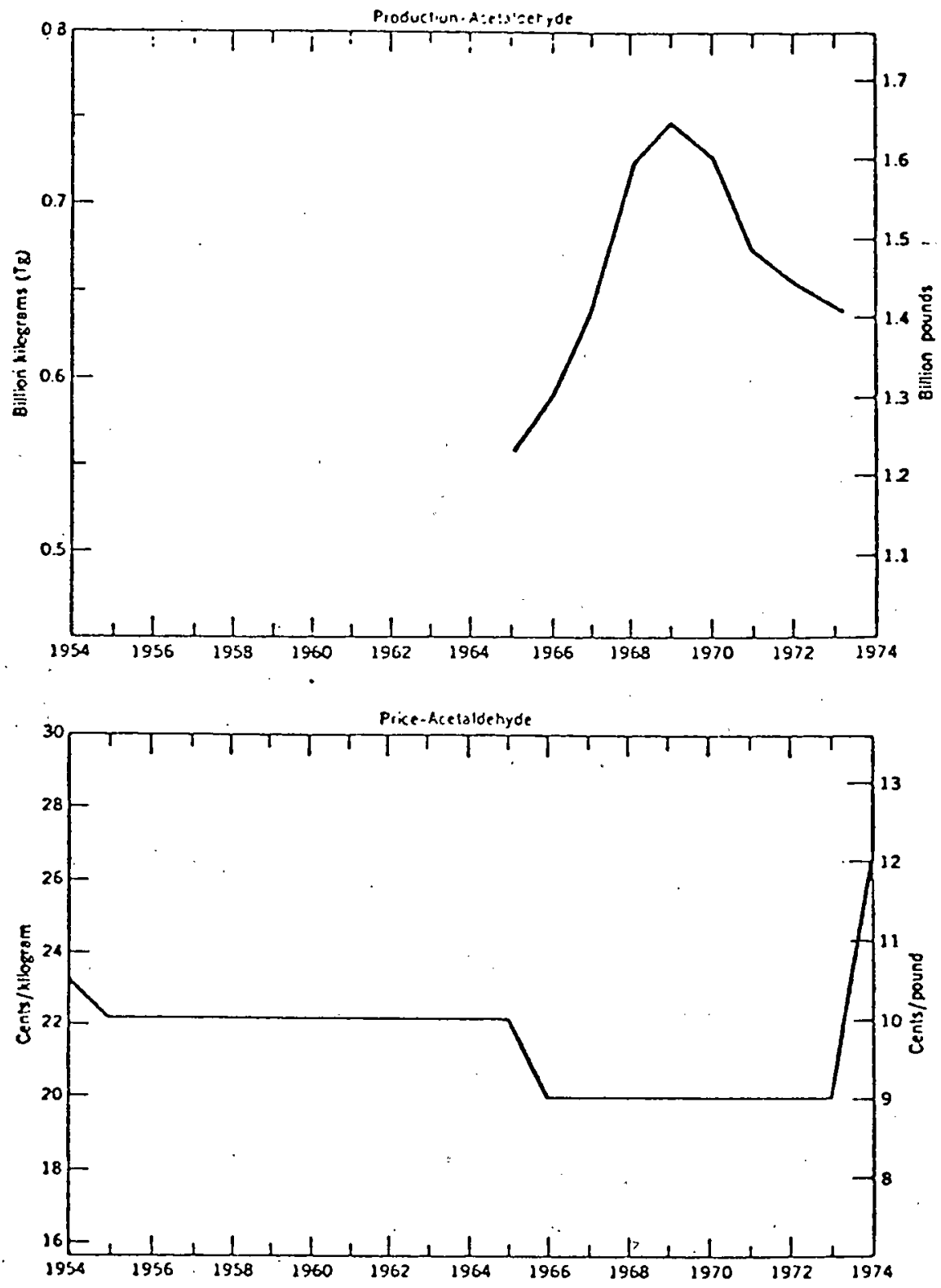

Fig. 7. Production and price of acetaldehyde to 1974. 

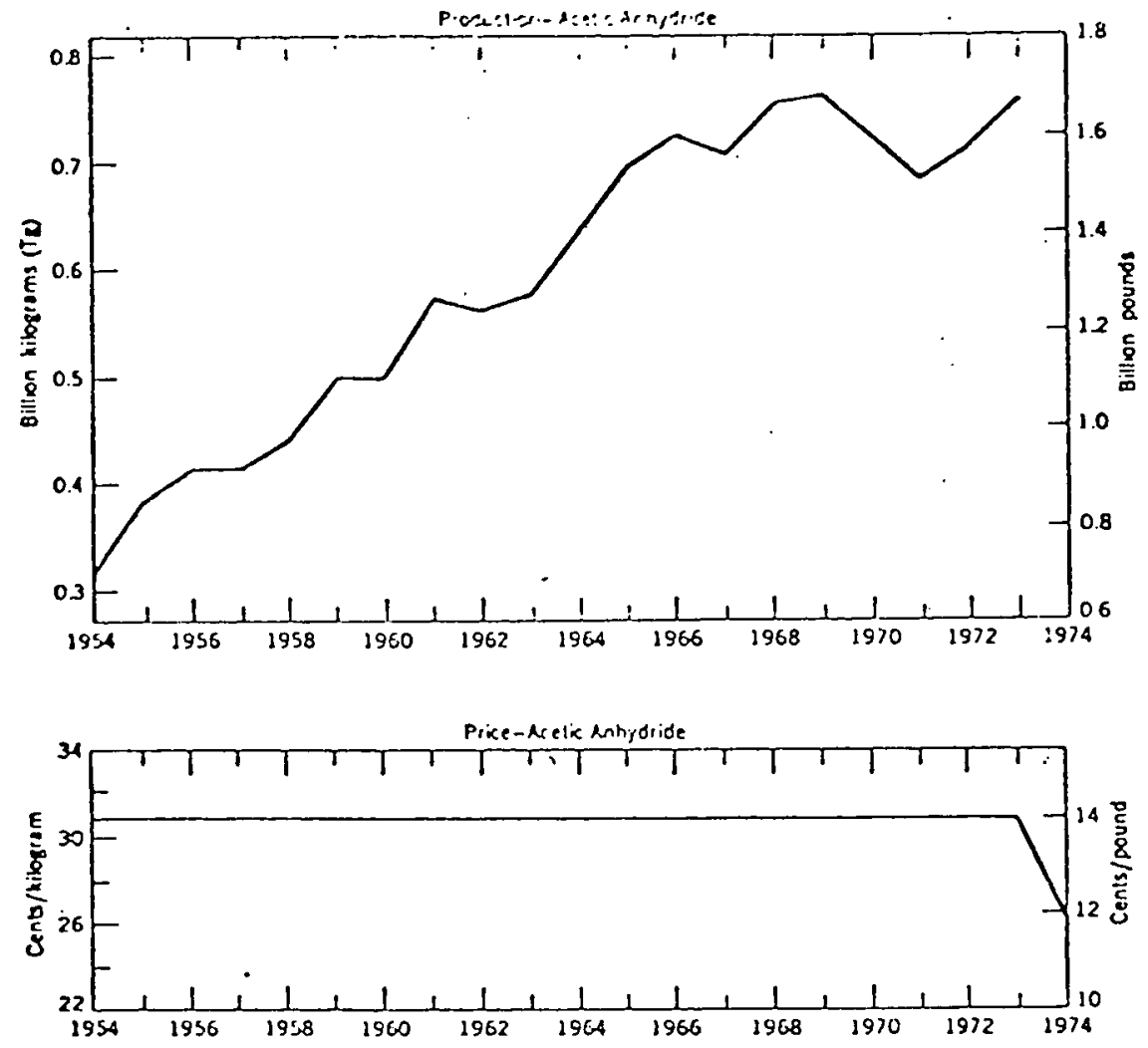

Fig. 8. Production and price of acetic anhydride to 1974 
pared by inwry and iguilo of Celanese Chemical (35). In addition to detailed process descriptions, they provided the following breakdown of companics and type of process currently in use in the USA:

TABLE 1-U.S. commercial acetic acid technology

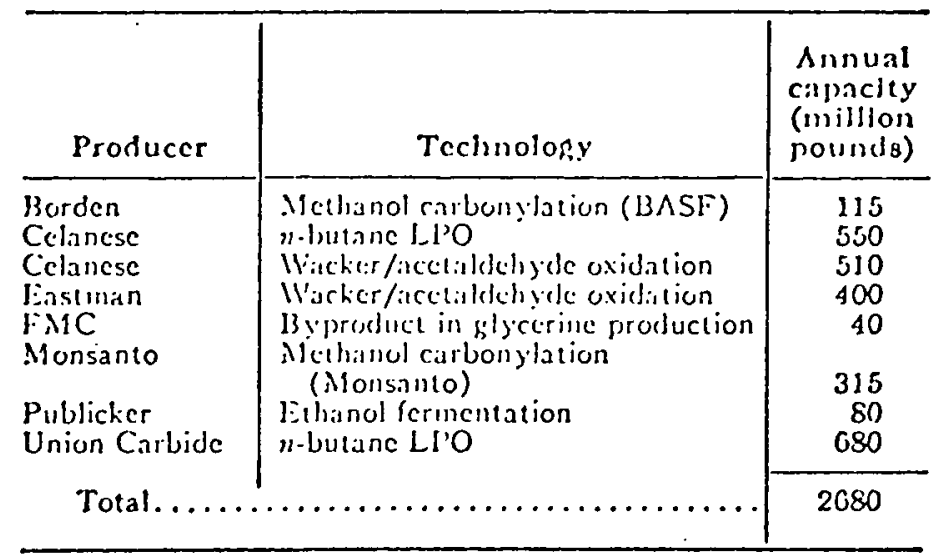

An anlysis of the processes for acetic acid would indicate that (a) if ethylene does not go too high in price, then the direct oxidation of ethylene to acetaldehyde, followed by its oxidation to acetic acid is competitive, and (b) if methanol does not go too high in price, then it too can be competitively converted to acetic acid by the new technology developed by Monsanto. This new process involves the use of an iodidepromoted rhodium catalyst to carbonylate methanol by means of $c 0$ at $175^{\circ} \mathrm{C}$ and $200 \mathrm{psig}$ with a 99 percent yield based on methanol. If very much co-product methanol is eventually produced from coal, or if methanol becomes a motor fuel blend commodity, then Monsanto might be in the driver's seat with its technology.

In summary, acetic acid has a very interesting growth pattern, tied directly with the acceptance of water-base paint emulsions and certain other aspects of the plastics field. However, the manufacturing of these polymers requires essentially anhydrous acetic acid (glacial of 99.5 percent or better) and, in some instances, requires acetic arhydride. In the author's opinion it will be difficult to produce such a product via fermentation in direct competition to the latest synthetic route technology, unless ethylene and methanol go higher in price than presently predicted.

\section{CONCLUSIONS AND RECOMMENDATIONS}

A number of pertinent conclusions can be drawn from the brief analysis made in this study, as follows:

1. It is not at all clear what the ultimate price of crude oil will be over the next two decades. It is clear that alternate sourccs of energy and new sources of oil will place the USA in a reasonably good position, regardless of what the OPEC nations do with respect to crude oil m-ices for cxports to Japan, Furope, USA (some percentage of our needs) and the rest of the World

2. The petrochemical industry is moving rapidly to altermate techmologics, 
cspecially co-product processes, wherein the influence of natural gas and light hydrocarbon prices will have less total impact upon its econornics.

3. The petrochemical industry continues to be in an excellent position with respect to (a) flexibility of operations tied in directly with the fuel aspects of refinery operations and (b) the tremendous size of its single-train lines and all the resultant economic advantages.

4. Carbon feedstocks from coal, cellulosics, $\mathrm{CO}$ and $\mathrm{CO}_{2}$ maj become substantailly cheaper than conventional natural gas and hydrocarbon feedstocks. The key economic question then becomes whether or not such differentials are sufficient to overcome the other economic factors herein outlined.

The author would like to make his recommendations at this point by interspersing appropriate comments as he proceeds. It is obvious that the petrochenical industry continues to be a formidable and worthy competitor to fermentation processes. Therefore, it is still advisable to direct fermentation toward arcas that are too complicated for conventional, large-scale petrochemical syntheses. This would include pharmaceuticals, animal feeds and human foodstuffs. After maiking this study, it would appear the SCP and the harvesting of microorganisms in various other systems still look attractive. How cellulosics will fare in competition with methanol is still not clear.

It is recommended that a long, hard look be taken at how to build the largest possible single-train fermentation system. Is a stirred tank economic or must some modified sewage plant system be used? It is recommended that fermentation reactions be separated more clearly with respect to those requiring reasonably fast mass transfer and those operating at low mass transfer. This might lead eventually to unique process equipment. Finally, a scrutiny of what unique chemicals and enzymes can be synthesized by microorganisms and plants should be done from all possible (and imaginative) viewpoints.

With respect to the specific chemicals considered in this study, the most economic feedstock should be determined as soon as possible. This should include wastes that are already collected in reasonable quantities. At the other end of the process, consideration should be given to utilizing n-butanol and/or acetic acid in aqueous solution form, going directly into the next use step. 
1. Enrjight, R.J., "The North Sea at Iast Begins to Give Up its Oil", Oil \& Gas J., 82 (June 30, 1975).

2. Wilson, H.M., "hlaska Pipeline May Beat July Target", Oil \& Gas J., 87 (Oct. 11, 1976).

3. Oil \& Gas J., 18 (Nov. 1, 1976).

4. Ibid, 42 (Sept. 13, 1976).

5. "Tenneco Pushes Strat Tests in Ultradeep Waters in Gulf", Oil \& Gas J., 53 (July 5, 1976).

6. "Socal, Shel. Poised off S. California", Oil \& Gas J., 81 (June 21, 1976).

7. "California, Alaska Offshore Activity Builds", Oil \& Gas J., I32 (Nov. 8, 3.976

8. "Doubling of Reserves Seen Possible", Oil \& Gas J., 22 (May 31, 1976).

9. Nelson, W.L., "What do Processing Plants Cost", Oil \& Gas J., 156 (May 17, 19:

10. "908 Jump in U.S. Oil Imports Seen by 1990", Oil \& Gas J., 133 (Nov. 8, 1976).

11. "Price Lids Lifted on Diesel Fuel and Middle Distillates", 54 (July 5, 1976).

12. Aalund, L.R., "Lead Stepdown' Threatens '77 U.S. Gasoline Crunch", Oil \& Gas J., 71 (July 26, 1976).

13. Spitz, P.H., "Propylene: Future Supply/Demand", Hydrocarbon Processing, 131 (July 1976).

14. Stork, K. et al, "More Petrochemicals from Crude", Hvdrocarbon Proc., 157 (Nov. 1974).

15. Faith, Keyes and Clark, "Industrial Chemicals" 4 th Ed, 376 (1974).

16. Chemical Marketer, Nov. 29, 1976.

17. Struth, B., "U.S. Ethylene Outlook", Hydrocarbon Proc., 124 (Nov, 1974).

18. Dosher, J.R., "Changing Petrochemical Feedstocks -- Causes and Effects", CEP, 15 (Sept. 1976).

19. Hosoi, T. and H.G. Keister, "Ethylene from Crude Oil", CEP 71, 63 (Nov. 1975).

20. Baggett, P.E., "Propylene Outlook", Hydrocarbon Proc., 126 (Nov. 1974).

21. Spitz, P.H., "Propylene: Future supply/demand", Hydrocarbon Proc., 131 (July 1976).

22. Spitz, P.H., "Propylene -- Key questions for the Future", CEP, 13 (Nov. 1976). 
23. Ericsson, R.L., "Butadiene Outlook", Hydrocarbon Proc., 123 (Nov. 1974).

24. Sherwin, M.B. and M.E. Frank, "Make Methanol by Three Phase Reaction", Hydrocarbon Proc., 122 (Nov. 1976).

25. Imhausen, $\mathrm{K}-\mathrm{H}$. et al, "Build Larger LDPE Plants", Hydrocarbon Proc., 155 (Hov. 1976).

26. Faith, Keyes and Clark, "Industrial Chemicals", 4th Ed., 178 (1974).

27. "Demand for Oil-recovery Chemicals is Estimated", Oil \& Gas J., 158 (May 17, 1976).

28. Fowler, R. et al, "Hyöroformylate Propylene at Low Pressure", Hydrocarbon Proc., 247 (Sept. 1976).

29. Brewster, E.A.V., "Low-pressure OxO Process Features Rhodium Catalyst", Chem. Eng., 90 (Nov. 8, 1976).

30. Weber, H. et al, "Make Plasticizer Alcohols this Way", Hydrocarbon Proc., 127 (Apr. 1976).

31. Langdon, W.K. and E.J. Schwoegler, "Propionic Acid", Ind. Eng. Chem. 43, 1011 (1951).

32. Faith, Keyes and Clark,. "Industrial Chemicals", 4th Ed., 8 (1974).

33. Ibid, p.l.

34. Ibid, p.16.

35. Lowry, R.P. and A. Aguilo, "Acetic Acid Today", Hydrocarbon Proc., 103 (Nov. 1974). 